\title{
A Treatment of Corticosteroid-Dependent Lepromatous Patients in Persistent Erythema Nodosum Leprosum A Clinical Evaluation of G.30320 (B663)
}

\author{
F. M. J. H. IMKAMP, O.D.S., M.B. (UTRECHT), L.A.H. (DU BLIN) \\ Medical Superintendent, Liteta Leprosarium, Zambia
}

Attention to the anti-inflammatory effect of B663 was first drawn by Browne ${ }^{34}$. In 2 patients receiving $600 \mathrm{mgm}$. B663 daily, Williams et $a l .{ }^{10}$ observed that the drug apparently controlled the signs of erythema nodosum leprosum (ENL).

Pettit $^{7}$ on the other hand, reported that B663 in a dosage of $100 \mathrm{mgm}$. daily had no dramatic effect in patients with very severe ENL (grades 3 and 4). He did, however, show that B663 had an anti-bacterial action in leprosy, thus confirming the early reports of Browne and Hogerzeil ${ }^{5}$, Barry and Conalty ${ }^{2}$ and Pettit et $a .^{8}$

It is of great importance to find a drug that is effective in the control of ENL, which, when severe, is most distressing to the patient and very difficult to treat. Jopling ${ }^{6}$ advocates the use of ACTH (cortico-trophin) or corticosteroids, with due regard to their limitations and serious side effects.

Because of the conflicting reports concerning the value of $\mathrm{B} 663$ in patients suffering from lepromatous leprosy with severe and longstanding ENL, we decided to put the drug to the test.

\section{THE PATIENTS}

Eighteen lepromatous patients $(10$ of them males) were selected for study.

Their ages ranged from 20-54 years when the B663 treatment was begun. In all of them the lepromin test (Mitsuda) was completely negative. All had suffered long periods of chronic severe ENL, classified $3+$ to $4+$ $\left(\right.$ Waters $\left.^{9}\right)$, before the trial started. They were corticosteroid dependent, and some could be considered as being addicted to the drug. They had received corticosteroids continuously for from 9 months to 4 years and 5 months, the average being 2 years 7 months. All the patients had previously been receiving anti-leprosy drugs, 16 of them DDS; all had also received thiambutosine, and 13 had had isoniazid. A number of drugs had been used on occasion, including thiacetazone, streptomycin, sulphorthormidine and ditophal. Each patient had his own pattern of ENL which recurred when attempts were made to reduce-even slightlythe dose of corticosteroids. All were bedridden, wasted and in very poor condition.

\section{METHOD OF INVESTIGATION AND FOLLOW-UP}

Chest X-ray examination was made of all patients at the beginning of the trial to exclude pulmonary tuberculosis. Regular urine tests were carried out for albumin, sugar and urobilinogen; haemoglobin levels and the white cell count were estimated every 2 months during the period of the trial; the differential white cell count was done at the beginning of the trial and after 12 months.

\section{LEPROSY INVESTIGATION}

Smears (Wade's technique) were taken from 7 sites every 2 months for calculation of the bacterial index (B.I.), and the morphological index (M.I.). 
TABLE I

\begin{tabular}{|c|c|c|c|c|c|c|c|c|c|}
\hline $\begin{array}{l}\text { Patient } \\
\text { Number } \\
\text { and } \\
\text { Sex }\end{array}$ & $\begin{array}{l}\text { Age } \\
\text { when } \\
\text { B } 663 \\
\text { started } \\
\text { years }\end{array}$ & $\begin{array}{l}\text { Date of } \\
\text { Admission } \\
\text { to } \\
\text { Liteta }\end{array}$ & $\begin{array}{l}\text { Length of } \\
\text { time on } \\
\text { Prednisolone } \\
\text { for ENL and } \\
\text { maximum } \\
\text { dose }\end{array}$ & $\begin{array}{l}\text { Date when } \\
\text { B663 started } \\
\text { and daily } \\
\text { dose }\end{array}$ & $\begin{array}{l}\text { Length of } \\
\text { time on } \\
\text { Prednisolone } \\
\text { or ACTH } \\
\text { after B663 } \\
\text { started }\end{array}$ & $\begin{array}{l}\text { Time } \\
\text { to } \\
\text { control } \\
\text { ENL }\end{array}$ & $\begin{array}{l}\text { Time } \\
\text { to } \\
\text { suppress } \\
\text { ENL }\end{array}$ & $\begin{array}{l}\text { Effect of } \\
\text { increased } \\
\text { dose of } B 663 \\
\text { on relapse } \\
\text { and max. } \\
\text { daily dosage }\end{array}$ & Comments \\
\hline$\stackrel{1}{\text { Male }}$ & 41 & 6.61 & $\begin{array}{l}4 \text { years } \\
3 \text { months } \\
50 \text { mgm. }\end{array}$ & \begin{tabular}{l}
\multicolumn{2}{c}{8.66} \\
$200 \mathrm{mgm} . \quad 1 / 12$ \\
$100 \mathrm{mgm} . \quad 1 / 52$ \\
$200 \mathrm{mgm} . \quad 1 / 52$ \\
then $100 \mathrm{mgm}$.
\end{tabular} & 4 months & 2 months & 4 months & $\begin{array}{l}\text { Very good } \\
200 \mathrm{mgm} \text {. }\end{array}$ & $\begin{array}{l}\text { Continuous ENL since 1962, extensive nodula- } \\
\text { tion with breakdown, lymphadenopathy. } \\
\text { abscess, fever, generalised neuritis, systemic } \\
\text { upset together with large bed sores and } \\
\text { emaciation, orchitis, insomnia. Now employed } \\
\text { as full-time clerical officer. }\end{array}$ \\
\hline$\stackrel{2}{\text { Male }}$ & 32 & 8.64 & $\begin{array}{l}4 \text { years } \\
1 \text { month } \\
50 \mathrm{mgm} .\end{array}$ & $100 \mathrm{mgm}$. & None & Few days & Few days & No relapse & $\begin{array}{l}\text { Generalised nodular eruption, malaise, high } \\
\text { fever, punched out ulceration on arms and legs. } \\
\text { August, 1967, lepromata resolved, ulcers } \\
\text { closed. Now leading normal life in lepro- } \\
\text { sarium. }\end{array}$ \\
\hline$\stackrel{3}{\text { Male }}$ & 28 & 1.62 & $\begin{array}{l}3 \text { years } \\
6 \text { months } \\
50 \text { mgm. }\end{array}$ & $\begin{array}{l}\text { } 7.66 \\
100 \mathrm{mgm} . \quad 6 / 12 \\
200 \mathrm{mgm} . \quad 2 / 52 \\
\text { then } 100 \mathrm{mgm} .\end{array}$ & None & Few days & $6 \frac{1}{2}$ months & $\begin{array}{l}\text { Very good } \\
200 \mathrm{mgm} \text {. }\end{array}$ & $\begin{array}{l}\text { Large painful nodules and ulnar neuritis. Now } \\
\text { working in leprosarium as ward attendant. }\end{array}$ \\
\hline$\stackrel{4}{\text { Male }}$ & 31 & 8.62 & $\begin{array}{l}2 \text { years } \\
10 \text { months } \\
50 \mathrm{mgm} \text {. }\end{array}$ & $100 \mathrm{mgm}$. & None & I week & 2 weeks & No relapse & $\begin{array}{l}\text { Initially extremely ill with severe deep bone } \\
\text { pain, painful intracutaneous nodules, ulnar } \\
\text { neuritis. Now leading normal life in lepro- } \\
\text { sarium. }\end{array}$ \\
\hline$\stackrel{5}{\text { Male }}$ & 30 & 2.63 & $\begin{array}{l}2 \text { years } \\
10 \text { months } \\
50 \mathrm{mgm} .\end{array}$ & $\begin{array}{l}\text { } 7.66 \\
100 \mathrm{mgm} . \quad 2 / 12 \\
200 \mathrm{mgm} . \quad 2 / 52 \\
\text { then } 100 \mathrm{mgm} .\end{array}$ & 6 weeks & I month & 2 months & $\begin{array}{l}\text { Verygood } \\
200 \mathrm{mgm} .\end{array}$ & $\begin{array}{l}\text { Multiple painful nodules with extensive } \\
\text { ulceration, ulnar neuritis, attacks of orchitis. } \\
\text { Now working as bricklayer in leprosarium. }\end{array}$ \\
\hline Male & 35 & 4.64 & $\begin{array}{l}2 \text { years } \\
2 \text { months } \\
50 \text { mgm. }\end{array}$ & $100 \mathrm{mgm}$. & None & Few days & Few days & No relapse & $\begin{array}{l}\text { Extensive painful nodules and neuritis, } \\
\text { arthritis, general malaise, deep bone pain and } \\
\text { insomnia. Now leading normal life in lepro- } \\
\text { sarium. }\end{array}$ \\
\hline $\begin{array}{c}7 \\
\text { Male }\end{array}$ & 44 & 3.64 & $\begin{array}{l}2 \text { years } \\
2 \text { months } \\
50 \text { mgm. }\end{array}$ & $\begin{array}{l}\text { } 6.66 \\
100 \mathrm{mgm} . \quad 2 / 12 \\
200 \mathrm{mgm} .10 \text { days } \\
300 \mathrm{mgm} .11 \text { days } \\
200 \mathrm{mgm} .6 / 52 \\
\text { then } 100 \mathrm{mgm} .\end{array}$ & 7 weeks & 10 weeks & 3 months & $\begin{array}{l}\text { Very good } \\
300 \mathrm{mgm} \text {. }\end{array}$ & $\begin{array}{l}\text { Generalised swelling and painful nodules, } \\
\text { iridocyclitis, median and ulnar neuritis, } \\
\text { oedema of legs, feet, deep pain, fever. Now } \\
\text { leading normal life in leprosarium. }\end{array}$ \\
\hline $\begin{array}{c}8 \\
\text { Male }\end{array}$ & 44 & 7.64 & $\begin{array}{l}2 \text { years } \\
1 \text { month } \\
50 \mathrm{mgm} \text {. }\end{array}$ & $100 \mathrm{mgm}$. & 8 days & 2 weeks & I month & No relapse & $\begin{array}{l}\text { Generalised nodular eruption, left ulnar } \\
\text { neuritis, lymphadenopathy, orchitis, fever. } \\
\text { Now leading normal life in leprosarium. }\end{array}$ \\
\hline$\stackrel{9}{\mathrm{Male}}$ & 54 & 5.64 & $\begin{array}{l}1 \text { year } \\
9 \text { months } \\
50 \text { mgm. }\end{array}$ & $\begin{array}{l}3.66 \\
100 \mathrm{mgm} .10 / 12 \\
200 \mathrm{mgm} . \quad 3 / 52 \\
\text { then } 100 \mathrm{mgm} .\end{array}$ & $\begin{array}{l}3 \text { months. } \\
\text { Stopped } 3 / 52 \\
\text { Short course } \\
3 / 52\end{array}$ & 6 months & 10 months & $\begin{array}{l}\text { Verygood } \\
200 \mathrm{mgm} .\end{array}$ & $\begin{array}{l}\text { Painful extensive lesions with ulcerations, } \\
\text { epididymitis, neuritis, recurrent fever, exten- } \\
\text { sive weight loss. Now employed as assistant } \\
\text { store keeper in leprosarium. }\end{array}$ \\
\hline $\begin{array}{c}10 \\
\text { Male }\end{array}$ & 25 & 9.64 & $\begin{array}{l}10 \text { months } \\
50 \mathrm{mgm} \text {. }\end{array}$ & $\begin{array}{l}7.66 \\
100 \mathrm{mgm} . \\
200 \mathrm{mgm} . \\
300 \mathrm{mgm} . \\
400 \mathrm{mgm} .\end{array}$ & $\begin{array}{l}\text { I month } \\
\text { Stopped } 2 / 52 \\
\text { Short course } \\
2 / 52\end{array}$ & I month & 1 year & $\begin{array}{l}\text { Excellent } \\
400 \mathrm{mgm} \text {. }\end{array}$ & $\begin{array}{l}\text { Very severe neuritie pain in ulnar and median } \\
\text { nerves, ulcerated skin lesions and fever. Now } \\
\text { ambulant patient in wards requiring daily } \\
\text { physiotherapy for contractures of hands. }\end{array}$ \\
\hline $\begin{array}{l}\text { II } \\
\text { Female }\end{array}$ & 43 & 10.61 & $\begin{array}{l}4 \text { years } \\
5 \text { months } \\
50 \text { mgm. }\end{array}$ & $100 \mathrm{mgm}$. & I week & Few days & I week & No relapse & $\begin{array}{l}\text { Extensive panniculitis and persistent, painful } \\
\text { lepromata with pain in arms and legs and fever. } \\
\text { Now performing normal domestic duties in } \\
\text { leprosarium. }\end{array}$ \\
\hline $\begin{array}{c}12 \\
\text { Female }\end{array}$ & 26 & 6.61 & $\begin{array}{l}4 \text { years } \\
2 \text { months } \\
75 \text { mgm. }\end{array}$ & $\begin{array}{l}8.66 \\
100 \mathrm{mgm} . \quad 2 / 52 \\
200 \mathrm{mgm} .10 / 52 \\
\text { then } 100 \mathrm{mgm} .\end{array}$ & I week & I week & 3 months & $\begin{array}{l}\text { Verygood } \\
200 \mathrm{mgm} \text {. }\end{array}$ & $\begin{array}{l}\text { Extensive nodular lesions, swelling of hands } \\
\text { and feet, fever, general malaise. Now per- } \\
\text { forming normal domestic duties in lepro- } \\
\text { sarium. }\end{array}$ \\
\hline $\begin{array}{c}13 \\
\text { Female }\end{array}$ & 31 & 8.61 & $\begin{array}{l}3 \text { years } \\
6 \text { months } \\
50 \text { mgm. }\end{array}$ & $\begin{array}{l}9.65 \\
100 \mathrm{mgm} .11 / 12 \\
200 \mathrm{mgm} .7 / 52 \\
\text { then } 100 \mathrm{mgm} .\end{array}$ & II months* & 3 weeks & 2 months & $\begin{array}{l}\text { Verygood } \\
200 \mathrm{mgm} .\end{array}$ & $\begin{array}{l}\text { * (For the first } 11 \text { months no attempt was made } \\
\text { to withdraw steroids completely, as this was } \\
\text { before the trial started.) Extensive painful } \\
\text { lesions with fever, headache and all peripheral } \\
\text { nerves painful. Arthritic ankles and knees, } \\
\text { swelling of hands and feet, general malaise. } \\
\text { Now performing normal domestic tasks in } \\
\text { leprosarium. }\end{array}$ \\
\hline$\stackrel{14}{\text { Female }}$ & 20 & 12.62 & $\begin{array}{l}2 \text { years } \\
6 \text { months } \\
50 \text { mgm. }\end{array}$ & \begin{tabular}{ll}
\multicolumn{2}{c}{8.66} \\
$100 \mathrm{mgm}$. & $6 / 52$ \\
$200 \mathrm{mgm}$. & $1 / 52$ \\
$300 \mathrm{mgm}$. & $6 / 52$ \\
$200 \mathrm{mgm}$. & $2 / 52$ \\
then $100 \mathrm{mgm}$.
\end{tabular} & $\begin{array}{l}\text { 6-day course } \\
9 \text { days after } \\
\text { starting } \\
\text { B } 663\end{array}$ & 12 weeks & 15 weeks & $\begin{array}{l}\text { Very good } \\
300 \text { mgm. }\end{array}$ & $\begin{array}{l}\text { Extensive painful nodules, laryngeal oedema, } \\
\text { polyarthritis, neuritis, lymphadenopathy, fever. } \\
\text { Now performing usual domestic duties in } \\
\text { leprosarium. }\end{array}$ \\
\hline
\end{tabular}


TABLE I (cont.)

\begin{tabular}{|c|c|c|c|c|c|c|c|c|c|}
\hline $\begin{array}{l}\text { Patient } \\
\text { Number } \\
\text { and } \\
\text { Sex }\end{array}$ & $\begin{array}{c}\text { Age } \\
\text { when } \\
\text { B663 } \\
\text { started } \\
\text { years }\end{array}$ & $\begin{array}{c}\text { Date of } \\
\text { Admission } \\
\text { to } \\
\text { Liteta }\end{array}$ & $\begin{array}{l}\text { Length of } \\
\text { time on } \\
\text { Prednisolone } \\
\text { for ENL and } \\
\text { maximum } \\
\text { dose }\end{array}$ & $\begin{array}{l}\text { Date when } \\
\text { B663 started } \\
\text { and daily } \\
\text { dose }\end{array}$ & $\begin{array}{l}\text { Length of } \\
\text { time on } \\
\text { Prednisolone } \\
\text { or ACTH } \\
\text { after B } 663 \\
\text { started }\end{array}$ & $\begin{array}{l}\text { Time } \\
\text { to } \\
\text { control } \\
\text { ENL }\end{array}$ & $\begin{array}{l}\text { Time } \\
\text { to } \\
\text { suppress } \\
\text { ENL }\end{array}$ & $\begin{array}{l}\text { Effect of } \\
\text { increased } \\
\text { dose of } \mathrm{B} 663 \\
\text { on relapse } \\
\text { and max. } \\
\text { daily dosage }\end{array}$ & Comments \\
\hline $\begin{array}{c}15 \\
\text { Female }\end{array}$ & 32 & 10.63 & $\begin{array}{l}1 \text { year } \\
10 \text { months } \\
50 \text { mgm. }\end{array}$ & $\begin{array}{l}9.66 \\
100 \mathrm{mgm} . \quad 4 / 12 \\
200 \mathrm{mgm} . \quad 1 / 12 \\
\text { then } 100 \mathrm{mgm} .\end{array}$ & None & Few days & 5 months & $\begin{array}{l}\text { Very good } \\
200 \text { mgm. }\end{array}$ & $\begin{array}{l}\text { Extensive nodular painful eruption, ulnar and } \\
\text { popliteal neuritis. General body pain. Dis- } \\
\text { charged to leprosarium and became pregnant } \\
\text { in August, } 1967 \text {. }\end{array}$ \\
\hline $\begin{array}{c}16 \\
\text { Female }\end{array}$ & 42 & 11.63 & $\begin{array}{l}1 \text { year } \\
6 \text { months } \\
50 \text { mgm. }\end{array}$ & \begin{tabular}{l}
\multicolumn{2}{c}{7.66} \\
$100 \mathrm{mgm} . \quad 2 / 12$ \\
$200 \mathrm{mgm} . \quad 2 / 12$ \\
$100 \mathrm{mgm} . \quad 5 / 12$ \\
$200 \mathrm{mgm} . \quad 4 / 12$ \\
$300 \mathrm{mgm}$. main- \\
tenance dose
\end{tabular} & 3 days & 2 months & 13 months & $\begin{array}{l}\text { Good } \\
300 \mathrm{mgm} \text {. } \\
\text { main- } \\
\text { tenance }\end{array}$ & $\begin{array}{l}\text { Continuous nodular eruption of large areas, } \\
\text { fever, insomnia, extensive neuritis. Now } \\
\text { performing normal domestic duties in lepro- } \\
\text { sarium. }\end{array}$ \\
\hline$\stackrel{17}{\text { Female }}$ & 40 & 4.64 & $\begin{array}{l}1 \text { year } \\
5 \text { months } \\
50 \text { mgm. }\end{array}$ & $\begin{array}{l}\text { } 7.66 \\
100 \mathrm{mgm} . \quad 3 / 12 \\
200 \mathrm{mgm} . \quad 1 / 52 \\
\text { then } 100 \mathrm{mgm} .\end{array}$ & None & 2 months & $3 \frac{1}{2}$ months & $\begin{array}{l}\text { s Verygood } \\
200 \mathrm{mgm} .\end{array}$ & $\begin{array}{l}\text { Repeated attacks of generalised nodular } \\
\text { eruptions, arthritis pains, bone pain in arms } \\
\text { and legs. Now performing normal domestic } \\
\text { duties in leprosarium. }\end{array}$ \\
\hline $\begin{array}{c}18 \\
\text { Female }\end{array}$ & 36 & 8.66 & $\begin{array}{l}9 \text { months } \\
50 \mathrm{mgm} .\end{array}$ & $\begin{array}{l}8.66 \\
100 \mathrm{mgm} .\end{array}$ & None & Few days & Few days & No relapse & $\begin{array}{l}\text { Extensive nodular eruptions with suppurating } \\
\text { ulcers, fever, swelling of feet, neuritis. Now } \\
\text { performing usual domestic duties in lepro- } \\
\text { sarium. }\end{array}$ \\
\hline
\end{tabular}

Biopsies were taken at the beginning, after 3 months and then at 6-monthly intervals (except the initial biopsy from patients who were too ill even for a biopsy). These were examined and reported on by the Leprosy Study Centre, London.

\section{ASSESSMENT OF RESPONSE}

Pettit $^{7}$ used the dose of ACTH required as a measure of assessing the progress of the patients. We concur that the amount of corticosteroids withdrawn, coupled with the clinical picture and biopsy reports, provides a reasonable method of assessing the anti-inflammatory action of a drug under investigation.

\section{ADMINISTRATION OF B663}

The absorption of $\mathrm{B} 663$ has been said to be enhanced when administered in olive oil $\left(\right.$ Barry $\left.^{1}\right)$, and Browne ${ }^{4}$ used $5 \mathrm{ml}$. of edible oil to facilitate absorption from the intestine. However, the addition of oil is now considered unnecessary (Vischer ${ }^{11}$ ); this was a great advantage since it would have been most difficult to persuade these critically ill patients to take a dose of oil by the mouth.

In the following case histories, our personal observations started in February, 1966; the previous facts and clinical data were summarised from clinical notes made before the writer assumed the medical care of the patients in the Liteta Leprosarium.
RESULTS

Table 1 gives a summary of the clinical findings and results of treatment. All the patients had been having repeated courses of prednisolone, starting with a dose of $50 \mathrm{mgm}$. (except Patient No. 12, whose maximum dose was $75 \mathrm{mgm}$.) and gradually reducing, but in all patients reduction of prednisolone precipitated a recurrence of ENL. When B663 treatment was begun, the patients were either on a maintenance dose of prednisolone or were just completing a course.

The starting dose of B663 was $100 \mathrm{mgm}$. per day without oil (except Patient No. 1, who began with $200 \mathrm{mgm}$. daily). Corticosteroids were discontinued at once in 7 patients, and discontinued gradually in from 1-28 days in 6 patients, and in from 1-2 months in 2 patients, and over 2 months in the other patients.

In the 7 patients (Nos. 2, 3, 4, 6, 15, 17 and 18) in whom corticosteroids were discontinued at the same time as B663 was started, ENL was rapidly controlled in all patients. Three of these patients (Nos. 3, 15 and 17) had a mild recurrence, which responded rapidly to an increase in dose of B663 to $200 \mathrm{mgm}$. per day.

Of the 6 patients (Nos. 8, 10, 11, 12, 14 and 16) whose corticosteroids were continued for from 1-28 days, 4 had recurrences of ENL. These occurred within a few days of stopping the drug in 3 patients (Nos. 10, 12 and 14), and after 6 weeks in Patient No. 16. All but one (No. 10) 
responded rapidly to an increase of $\mathrm{B} 663$ to 200 or $300 \mathrm{mgm}$. per day (without prednisolone). Patient No. 10 had severe ulnar neuritis, was emotionally unbalanced and addicted to prednisolone; he was given a 2 weeks' course of prednisolone while $\mathrm{B} 663$ was continued at a dose of $100 \mathrm{mgm}$. daily. Patient No. 14 was given a 6-day course of prednisolone 9 days after beginning treatment with B663. Three of this group had further recurrences of ENL (Patient No. 14 after 6 weeks, and Patients Nos. 10 and 16 at 9 months after the start of B663). All 3 responded very well to a temporary increase dose of B663 alone.

The 2 patients (Nos. 5 and 7 ) in whom the corticosteroids were continued for 2 months, had a recurrence of ENL within one month of stopping the drug, but responded very well to an increase of B663 alone, for a short period.

Three patients (Nos. 1, 9 and 13) continued taking corticosteroids for a long period together with B663. In Patients Nos. 1 and 9, very gradual reduction was particularly necessary in these very ill, corticosteroid dependent and emaciated patients. Patient No. 1, who started with $200 \mathrm{mgm}$. B663 daily while the dose of prednisolone was being gradually reduced, had a recurrence of ENL when the B663 daily was reduced to $100 \mathrm{mgm}$ daily while he was still having $3 \mathrm{mgm}$. prednisolone daily. This recurrence was rapidly controlled when B663 was again increased to $200 \mathrm{mgm}$. daily, for one week. No further ENL occurred when the prednisolone was eventually stopped, and the dose of B663 remained at $100 \mathrm{mgm}$. daily.

In Patient No. 9, a recurrence of ENL 16 days after steroids were stopped, necessitated a further 3 weeks' course of steroids. After 4 months on $100 \mathrm{mgm}$. B663 daily alone, the patient had a further recurrence of ENL, which responded to an increase in dose of $\mathrm{B} 663$ $200 \mathrm{mgm}$. daily for 3 weeks, and no prednisolone. The patient is now well controlled on $100 \mathrm{mgm}$. B663 daily. As this patient was already on B663 before the trial started, he was included in the study.

In Patient No. 13, no attempt was made to stop steroids when B663 was given (Sept., 1965), as this was before the trial started. Two weeks after steroids were stopped, the patient had a recurrence of ENL, which responded to an increase dose of B663, $200 \mathrm{mgm}$. daily, alone.

WEIGHT GAIN AND LOSSES

In a few patients, weight loss was observed at the beginning of the trial. This was attributed to loss of oedema following withdrawal of corticosteroids. (Patients Nos. 2, 4, 15 and 18 losing $4,5,3$ and $10 \mathrm{lbs}$. respectively, this weight being regained in all cases, except No. 2 whose nett loss was 2 lbs.) Of far gieater significance is the increase in weight of the patients who had been seriously ill and emaciated. This can only be appreciated by seeing the individual figures, shown in Table 2 . Nine of the 18 patients gained more than $10 \mathrm{lbs}$., and 5 of these gained $17 \mathrm{lbs}$. or more. This was all true weight gain, since none of the patients had any sign of oedema while on B663 treatment.

\section{TABLE 2 \\ Weight Gains}

\begin{tabular}{|c|c|c|c|c|c|}
\hline Patient & & & Patient & & \\
\hline No. 1 & - & 99 lbs. & No. 11 & - & $17 \mathrm{lbs}$ \\
\hline No. 3 & - & Constant & No. 12 & - & $6 \mathrm{lbs}$. \\
\hline No. 5 & - & $11 \mathrm{lbs}$. & No. 13 & - & $2 \mathrm{lbs}$. \\
\hline No. 6 & $\longrightarrow$ & $12 \mathrm{lbs}$. & No. 14 & - & $18 \mathrm{lbs}$. \\
\hline No. 7 & - & 3 lbs. & No. 16 & - & $11 \mathrm{lbs}$ \\
\hline No. 8 & - & 8 lbs. & No. 17 & - & $5 \mathrm{lbs}$. \\
\hline No. 9 & - & $27 \mathrm{lbs}$ & No. 18 & - & 29 lbs. \\
\hline No. 10 & - & 12 lbs. & & & \\
\hline
\end{tabular}

EFFECT ON $M$. leprae

Table 3 shows the Bacteriological Index (B.I.) and the Morphological Index (M.I.) at the outset of the trial in 1966 and at the end of 1967 . An earlier figure is given for Patients Nos. 4 and 9, in whom B663 was given before the trial period. No earlier figure is given for Patient No. 13, although she also began taking B663 before the trial.

In 5 patients (Nos. 2, 3, 7, 11 and 14), the initial M.I. is higher than would be expected in patients who had been on anti-leprosy treatment for a considerable time; this may suggest that although cortico-steroids control ENL, their use may in some way have affected the action of anti-leprosy drugs. 
TABLE 3

B.I. and M.I. at the start of $B 663$

to the end of 1967

\begin{tabular}{|c|c|c|c|c|}
\hline $\begin{array}{c}\text { Patient } \\
\text { No. }\end{array}$ & $\begin{array}{c}B . I . \\
\text { mid-1966 }\end{array}$ & $\begin{array}{c}M . I . \\
\text { mid-1966 }\end{array}$ & $\begin{array}{c}B . I . \\
\text { end } 1967\end{array}$ & $\begin{array}{c}M . I . \\
\text { end } 1967\end{array}$ \\
\hline 1 & 3.1 & $0 \%$ & 1.0 & $0 \%$ \\
\hline 2 & 4.7 & $3.8 \%$ & 3.8 & $6 \%$ \\
\hline 3 & 4.7 & $15.0 \%$ & 4.2 & $0.2 \%$ \\
\hline \multirow{2}{*}{4} & $\int 31.3 .66$ & & & \\
\hline & 4.2 & $6.4 \%$ & 3.2 & $0 \%$ \\
\hline 5 & 2.0 & $0.4 \%$ & 1.1 & $0 \%$ \\
\hline 6 & 2.7 & $0 \%$ & 1.1 & $0 \%$ \\
\hline 7 & 4.2 & $6.2 \%$ & 3.4 & $0.5 \%$ \\
\hline 8 & 3.8 & $0.1 \%$ & 1.5 & $0 \%$ \\
\hline \multirow{2}{*}{9} & ( 29.3.66 & & & \\
\hline & 4.8 & $2.0 \%$ & 4.8 & $1.0 \%$ \\
\hline 10 & 3.8 & $1.7 \%$ & 3.1 & $0 \%$ \\
\hline 11 & 4.1 & $3.7 \%$ & 4.1 & $0.2 \%$ \\
\hline 12 & 4.5 & $0.7 \%$ & 3.0 & $0 \%$ \\
\hline 13 & 1.8 & $0 \%$ & 0 & $0 \%$ \\
\hline 14 & 4.7 & $4.1 \%$ & 2.5 & $0.1 \%$ \\
\hline 15 & 4.8 & $1.4 \%$ & 3.2 & $0 \%$ \\
\hline 16 & 2.4 & $0 \%$ & 0.1 & $0 \%$ \\
\hline 17 & 4.1 & $2.1 \%$ & 3.5 & $0.5 \%$ \\
\hline 18 & 5.0 & $2.5 \%$ & 4.1 & $0.2 \%$ \\
\hline
\end{tabular}

The overall picture of the smears taken every 2 months during the trial, shows a fall in the B.I. in all but 2 patients. The M.I. fell in all patients. All smears were examined by the same experienced laboratory technician throughout the trial. There was no evidence of the development of resistance to $\mathrm{B} 663$ in any patient.

\section{DOSAGE OF B663}

In most patients, $100 \mathrm{mgm}$. per day proved an adequate maintenance dose. Twelve patients at some time required an increased dose, which controlled a recurrence of ENL. This was either 200 or $300 \mathrm{mgm}$. per day, except in one patient who needed $400 \mathrm{mgm}$. per day. The dose used depended on the response to the initial increase.

The dose was subsequently reduced to $100 \mathrm{mgm}$. per day, with complete control in all patients except one, who required a daily dose of $300 \mathrm{mgm}$. This patient's weight being $178 \mathrm{lbs}$., it is considered that the body weight may be related to the dosage required.

SIDE EFFECTS OF B 663

\section{Gastro-intestinal}

Patients Nos. 1, 10 and 12 had diarrhoea. All were taking $200 \mathrm{mgm}$. per day at that time.
Patient No. 1 had been on treatment for 3 weeks and Patient No. 12 for 7 weeks. In all patients, the diairhoea cleared rapidly when treatment was stopped for a few days. Patient No. 1 had a recurrence of diarrhoea at 8 weeks while taking $100 \mathrm{mgm}$. B663 daily. After 11 months, Patient No. 10 developed diarrhoea while on $200 \mathrm{mgm}$. per day. This patient also had some vomiting when on $100 \mathrm{mgm}$. per day, early in the investigation. At that time he was suffering from considerable emotional upset and was very reluctant to take $\mathrm{B} 663$ and demanded corticosteroids. This probably aggravated the vomiting. He did not vomit or have diarrhoea later when on a course of increased dosage of B663, even though at one time this reached $400 \mathrm{mgm}$. per day.

\section{Pigmentation}

All patients were told at the beginning of the trial that their skin would become darker. None of the patients objected, for at that time the majority were too ill to care, and later they regarded it as a sign that the medicine was 'doing good'.

There appeared to be no difference in the density of pigmentation between those patients who have received $100 \mathrm{mgm}$. daily and those who received a higher dosage. The parts of the body exposed to light were darker than the covered parts. This was especially noticeable in the men wearing short trousers and shortsleeved shirts. Darker pigmentation in the women was seen above the neckline of the dresses and on the forearms.

\section{Eyes}

The eyes of all patients were subjected to slit-lamp examination at the end of the trial. There was no evidence of active ocular disease or abnormal pigmentation of the conjuctival or corneal epithelium. One patient showed signs of cataracts (which had been noted before the treatment with B663 had been started).

\section{Pregnancy}

One patient (No. 15) had been on treatment with B663 from September, 1966, at a daily

A Clinical Evaluation of G30320 (B663)

$12: 3$ 
dose of 100 mgm., apart from one month when she received $200 \mathrm{mgm}$. per day. In November, 1967, she delivered a normal healthy female child, weighing 7 lbs. $12 \frac{1}{2}$ ozs. Her pregnancy was normal and there was no increase in M.I. during pregnancy. The skin of the baby was thought to be slightly darker than is usual in this part of the world.

\section{Laboratory Results}

During the trial no abnormalities were reported in the blood or urine tests performed.

\section{Biopsies}

All biopsy reports confirmed the clinical diagnosis of lepromatous leprosy-and the last report of every patient stated: no evidence of any bacillary activity.

\section{DISCUSSION}

All the 18 patients in this investigation had been on a high dosage of prednisolone for periods varying from 9 months to 4 years and 5 months, an average of 2 years and 7 months.

They had been given frequent courses of high dosage, the usual regime being to give $50 \mathrm{mgm}$. per day at the onset of acute ENL and gradually reducing till the lowest maintenance dose was attained. In all patients, repeated attempts at withdrawal had been followed by recurrence of ENL. Four patients had developed moon-face, and another had osteoporosis and collapsed vertebrae, together with bilateral posterior capsular cataracts. All the patients were seriously ill, and so addicted to prenisolone that they demanded an increased dose at the first symptoms of recurrence of ENL. The anxiety they experienced on the withdrawal of prednisolone when B663 was begun, was quite genuine, and required high dosages of tranquillisers, a situation which persisted until the patients became aware that the ENL could be controlled by B663 alone.

After cessation of steroids, the ENL in 6 patients (Nos. 2, 4, 6, 8, 11 and 18) was completely controlled by B663, $100 \mathrm{mgm}$. daily. In a further 7 patients (Nos. 1, 3, 12, 13, 15, 16 and 17 ) the ENL was controlled by a temporary increase of dose to 200 or $300 \mathrm{mgm}$. a day. (Patient No. 1 was still on a reducing scale of prednisolone.) None of these 13 required further courses of prednisolone.

Five patients (Nos. 5, 7, 9, 10 and 14) were given further prednisolone together with 100 mgm. B663 daily when ENL recurred in the early stages of the trial. At this time, a cautious procedure was thought to be necessary in view of the patients' serious condition. In retrospect, it seems likely that the doses of steroids had been reduced too rapidly. Later recurrences were controlled by B663 alone, at daily dosages from $200 \mathrm{mgm}$. to $400 \mathrm{mgm}$. All could be reduced again and were controlled by $100 \mathrm{mgm}$. per day.

It is important to point out that the dose necessary to control ENL or a recurrence of ENL varies from patient to patient. If all other patients had been maintained on $100 \mathrm{mgm}$. per day, in only 6 out of the 17 (Patient No. 1 started on $200 \mathrm{mgm}$. per day) would the ENL have been controlled. This different dose regime may well explain the discrepancies apparent between Pettit's ${ }^{7}$ findings and ours.

As described previously, effective antibacterial action was attained and sustained in all patients. One patient (No. 13) showed complete resolution of all signs and symptoms of active leprosy, with complete clearance of B.I. and M.I.

Side-effects were minimal, and there were no toxic effects. Patients improved gieatly in general condition, as shown by weight gain, and all are leading a normal life; a number are employed in the leprosarium. There has been no adverse effect on pregnancy or on the foetus.

\section{SUMMARY}

A series consisting of 18 lepromatous patients is reported; all had severe ENL, which was just controllable only with large doses of corticosteroids. They were all initially bedridden, severely ill and steroid-dependent. After an average period of 2 years and 7 months of corticosteroid treatment, they began treatment with G30320 (B663) at a dose of $100 \mathrm{mgm}$. per day, except Patient No. 1, who began with $200 \mathrm{mgm}$. daily. It was then possible to stop or 
withdraw steroids in all patients. Six patients had no recurrence of ENL, 7 patients had some recurrences which were controlled by a temporary increase of B663. Five patients were given prednisolone together with $100 \mathrm{mgm}$. B.663 daily, for relapses early in the trial, but subsequent relapses were controlled by an increase of B663 dosage alone. Seventeen patients were ultimately controlled with a maintenance dose of $100 \mathrm{mgm}$. of B663 per day, and one patient (No. 16) required $300 \mathrm{mgm}$. per day as a maintenance dose.

Over a period of from 14-18 months, all patients showed a steady improvement in B.I. and M.I. (except for 2 whose B.I. remained stationary). The patients showed marked clinical improvement, all are now leading a normal life, and some are employed in the leprosarium.

Side-effects were minimal, and the hyperpigmentation that developed was cheerfully accepted. All patients are most enthusiastic about B66:3 treatment.

It is considered that this drug represents a real advance in the treatment of ENL in that it will control persistent recurrence of such a degree as otherwise to require high dosages of corticosteroids, at the same time providing active chemotherapy.

\section{ACKNOWLEDGEMENTS}

I wish to thank Dr. M. M. Nalumango, Permanent Secretary for Health, Zambia, for his permission to publish this article; Dr. D. J. Harman, of the Leprosy Study Centre, for his most helpful biopsy reports; Mr. C. M. Phillips, o.B.E., F.R.C.S., for his ophthalmological reports;
Mrs. J. Corbridge, Laboratory Technician at Liteta Leprosarium, who assisted me in conducting this investigation and assembled the necessary data and records; and Messrs. J. R. Geigy for their generous supplies of B663.

Finally I wish to thank my patients for their co-operation and confidence which in the beginning of the trial was severely tested.

\section{REFERENCES}

1. BARRY, C. B., et al. Factors influencing the antituberculosis activity of the Rimino-compounds. Bull. Un. int. Tuberc., 29, $582-593$ (1959).

2. BARRY, v. c. and CONAlty, M. L. The antimycobacterial activity of B663. Lep. Rev., 33, 3-7 (1965).

3. BRowne, S. G. B663. Possible anti-inflammatory action in lepromatous leprosy. Lep. Rev., 36, 9-11 (1965).

4. BRowne, s. G. B663 (Geigy). Further observations on its suspected anti-inflammatory action. Lep. Rev., 37, 141-145 (1966).

5. BRowne, S. G. and Hogerzeil, L. M. (a) B663 in the treatment of leprosy, Lep. Rev., 33, 6-10 (1962). (b) Apparent resistance of $M$. leprae to $\mathrm{B} 663$. Lep. Rev., 33, 185-189 (1962).

6. Jopling, w. H. Leprosy in Theory and Practice. Cochrane, R. G. and Davey, T. H. Second Edition.

7. PETtit, J. H. S. The treatment of Erythema Nodosum Leprosum with B663. A controlled study. Int. J. Lepr., 35, 1, $11-16$ (1967).

8. PETTIT, J. H. S., REES, R. J. W. and RIDLEY, D. S. Chemotherapeutic Trials in Leprosy. Pilot trial of a rimino-phenazine derivative, $\mathrm{B} 663$, in the treatment of lepromatous leprosy. Int. J. Lepr., $35,1,25-33$ (1967).

9. Waters, M. F. R. Chemotherapeutic trials in Leprosy. I. Comparative trial of Macrocyclon plus Dapsone and Dapsone alone in the treatment of lepromatous leprosy. Lep. Rev., 34, 173-192 (1963).

10. Williams et al. Experience with B663 in the treatment of leprosy. Int. J. Lepr., 33, 767-775 (1965).

11. Vischer, w. Geigy, Basle. Personal communication. 